\section{AN ANALYSIS OF 'A MILLION DREAMS' SONG : FIGURATIVE LANGUAGES AND MORAL INTERPRETATIONS}

\author{
Eka Fajar Rahmani \\ Teacher Training and Education Faculty, Universitas Tanjungpura \\ ekasastria10@fkip.untan.ac.id
}

Figurative

learning,

Moral

interpretation

\begin{abstract}
The qualitative study aims at presenting the results of figurative languages and moral interpretations of A Million Dreams songs. From the analysis, it was indicated that there were eleven types of figurative languages and two moral values interpreted from the song. The details of figurative language analysis are 13 imageries $(20,6 \%), 4$ personifications (6,3\%), 2 paradoxes (3,7\%), 14 symbols (22,22\%), 6 idioms (9,52\%), 9 hyperboles $(14,28 \%), 8$ repetitions (12,69\%), 1 simile (1,58\%), 1 metaphor (1,58\%), 1 assonance $(1,58 \%)$, and 6 consonances $(9,52 \%)$. Meanwhile, the moral values were about (1) it was important for young people to have visions for a better future lives; and (2) having companions who could be a place for sharing was valuable. In short, as being comprehended that figurative languages and moral values are two educative elements in songs, the researcher expected that the results of this study would bring significances to the target readers.
\end{abstract}

Keywords: figurative learning, moral interpretation, Song

\title{
INTRODUCTION
}

Learning English nowadays should not be limited to a classroom context with the textbooks or modules as the only sources of the learning. An old - fashioned paradigm of learning English has to be changed into a broader one that English can be learned in any contexts with various learning media (Oroujlou, 2012). One of the media that has been proven by its effectiveness to enhance English learning is song (Pratiwi, 2018). One experimental study conducted by Ningsih (2019) mentioned that students gained more interests and motivation in learning the classroom activity after being taught through songs. Significant improvement on scores also happened after songs were used. Other studies indicated that similar results that songs were effective enough to improve learners' skills in English including listening, speaking, pronunciation, and also vocabulary (Shen, 2009; Millington, 2011). Likewise, songs are also able to encourage learners to spend more time to learn English that they find them interesting, fun, and tranquil (Kurnierek, 2016;

SPECTRAL Jurnal Ilmiah STBA Vol.6 No.2 Juni 2020 ISSN 0216-3381 Pratiwi, 2018; Hendrawaty \& Nurhayati, 2019). 
Figurative learning, Moral interpretation

\section{6}

Nevertheless, when it is analyzed deeper, it can be figured out that there are more features of English available in songs, such as figurative languages. Figurative languages are parts of literary devices defined as idiomatic expressions which have non-literal or interpretative meanings that include comparisons, connotations, and other non-literal meanings (Keraf, 2009; Harya, 2016). There are several types of figurative languages which are divided based on their uses, such as hyperbole, personification, metaphor, simile, paradox, assonance, consonance, symbol, idiom, onomatopoeia, alliteration, and repetition. Each of these types has different functions, refers to different meanings, and are uttered by people to show different intentions. For example, a hyperbole is defined a rhetorical trope by means of which statements are made that are obviously exaggerated and thus untrue or unwarranted (Lausberg, 1998 as cited in Henkemans, 2009, p. 1). Meawhile, a personification or also known as prosopopoeia refers to the rhetorical figure by which something not human is given a human identity (Melion \& Ramakers, 2016). Both hyperbole and personification are used intentionally to refer to connotative meanings. However, they are uttered differently that hyperbolic utterance uses exaggeration while personification uses human traits to the non-human.

In song lyrics, figurative languages provide poetic sense that add the artistic value to the songs (Aprianti, Zulfadhli, \& Thahar, 2012). Composers use figurative languages in songs because they allow them to express more feelings, thoughts, and ideas in various languages (Arifah, 2016) In line with that, Collie and Slater (1987 as cited in Rohani, Arsyad \& Diani, 2018) suggested four reasons why figurative languages are used in literary work: (1) valuable authentic material; (2) cultural enrichment; (3) language enrichment; and (4) personal involvement. In psychological perspectives, figurative languages also have the gist to bring positive ambience that is useful to boost the mood of the listeners because they have the ability to give therapeutic function to people (Cardin, 2004). Besides, the courteous element in figurative languages might give an honor to the people (in this case is the listeners or the readers) whom the composers talk to through the songs (Padillah, Firmawan, \& Purwaningsih, 2016).

In addition to the aforementioned functions of figurative languages, from English language learning (ELL) perspective, figurative languages are one of essential literary devices in the learning vocabulary. Through figurative languages, the students are able to grab or understand the meaning of English expressions uttered by English users (Rohani 
\& Arsyad, 2018). Additionally, figurative languages are able to help EFL learners to Figurative overcome barriers to acquire more advanced vocabulary level in order to express their feelings and thoughts precisely in English like the native speakers (Doiz \& Elizari, 2013; learning, Moral interpretation MacArthur, 2010). The use of figurative language as a non-literal or idiomatic language might expand learners' vocabulary, as well as make their language more expressive and closer to their feelings (Danessi in Doiz \& Elizari, 2013, p. 50). Therefore, by understanding and using the figurative languages, EFL learners do not only enrich their vocabulary to be more sophisticated but also help them to use English in expressive ways as they convey their thoughts and feelings in verbal or even in non-verbal communications.

Besides figurative languages, as a literary work, the song also contains moral values that is useful for the listeners or the readers. According to Baumbach, Grabes \& Nünning (2009), literary works not to exclude songs can be reflections of lives, reinforcement and constructions of the norms and values in lives. By definition, moral values can be defined as the standards of directing one's behaviors which function to give shape to themselves and to social life (Eglimez, 2016). Through understanding them, ones learn to discriminate between good and bad, right and wrong towards the social rules or set of manners (Yazici, cited in Egilmez, 2016). In other words, if listeners or readers learn the song lyrics, they are given big opportunities to grab the moral values in the songs which can be beneficial if they apply them.

The background above led the researcher to conduct a qualitative research focusing on analyzing the figurative languages and the moral values of a song. The writer chose a song from The Greatest Showman original soundtrack entitled Million Dreams. The writer believed that through the song, the EFL learners would get more than entertainment that they could learn English, as well as the moral lessons. There have been lots of researchers did researches on figurative languages in songs in Indonesia, such as Setiawan (2014), Listiani (2015), Arifah (2016), Islami (2019), and many more. However, there are still limited researches talking about moral values that could be grasped by learners when the songs are used as the learning media; and this was the gap that the researcher would like to bridge. By doing so, the researcher believed that the results of this research would be more significant for the targeted readers, especially the EFL learners. 
Figurative learning, Moral interpretation 118

\section{METHODS}

This study was conducted based on qualitative approach. The subject was a song entitled A Million Dreams written by Benj Pasek and Justin Paul released in 2017. It is the original soundtrack of The Greatest Showman movie which was also released in 2017. This song was popular in Indonesia that there were more than twenty singers in Youtube covered it. The analysis was concentrated on figurative languages and moral messages presented in the song lyric. This song caught the writer's interest because its popularity amongst teenagers in Indonesia who were EFL learners, as well. In analyzing the songs, the writer first determined the figurative language on each line. After that, the writer did an in - depth analysis to the lyrics in order to find out the moral lessons. Finally, the results would be displayed and narrated into the findings and discussion section.

\section{FINDINGS AND DISCUSSION}

\section{Figurative languages analysis}

The lyric of A Million Dreams has 21 clauses, excluding the repeated refrain. After those clauses were analyzed, there found 63 figurative languages from ten different types. The details of the analysis can be seen in Chart 1 and Table 1 below.

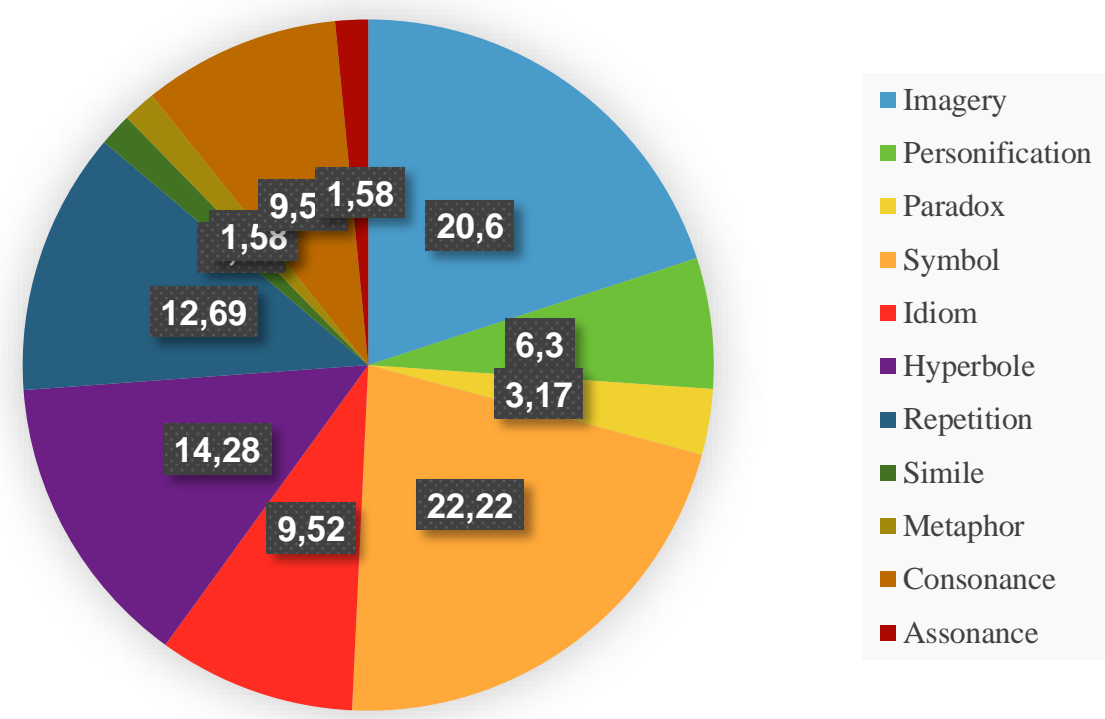

Diagram 1 Figurative Languages Distribution 
Table 1 Figurative Language Analysis

\begin{tabular}{|c|c|c|}
\hline No & Lyric & Type of Figurative Language \\
\hline 1. & $\begin{array}{l}\text { I close my eyes and I can see the world that's wait- } \\
\text { ing up for me that I call my own }\end{array}$ & $\begin{array}{l}\text { Imagery, personification, symbol, para- } \\
\text { dox }\end{array}$ \\
\hline 2. & $\begin{array}{l}\text { Through the dark, through the door, through where } \\
\text { no one's been before but it feels like home }\end{array}$ & $\begin{array}{l}\text { Imagery, hyperbole, simile, symbol, } \\
\text { repetition }\end{array}$ \\
\hline 3. & They can say, they can say it all sounds crazy & Idiom, hyperbole, repetition \\
\hline 4. & They can say, they can say I've lost my mind & Idiom, hyperbole, repetition \\
\hline 5. & I don't care, I don't care so call me crazy & Repetition, consonance \\
\hline 6. & We can live in a world that we design & Imagery, idiom, symbol, consonance \\
\hline 7. & $\begin{array}{l}\text { "Cause every night I lie in bed } \\
\text { The brightest colors fill my head }\end{array}$ & Imagery, personification, assonance \\
\hline 8. & A million dreams are keeping me awake & Imagery, personification, hyperbole \\
\hline 9. & $\begin{array}{l}\text { I think of what the world could be a vision of the } \\
\text { one I see }\end{array}$ & $\begin{array}{l}\text { Imagery, metaphor, symbol, conso- } \\
\text { nance }\end{array}$ \\
\hline 10. & A million dreams is all it's gonna take & Hyperbole, symbol, personification \\
\hline 11. & A million dreams for the world we're gonna make & Hyperbole, symbol, imagery \\
\hline 12. & There's a house we can build & Symbol, imagery \\
\hline 13. & $\begin{array}{l}\text { Every room inside is filled with things from far } \\
\text { away }\end{array}$ & Imagery, symbol, hyperbole \\
\hline 14. & $\begin{array}{l}\text { The special things I compile, each one there to } \\
\text { make you smile on a rainy day }\end{array}$ & Symbol, imagery, idiom, \\
\hline 15. & They can say, they can say we've lost our minds & $\begin{array}{l}\text { Idioms, hyperbole, repetition, conso- } \\
\text { nance }\end{array}$ \\
\hline 16. & I don't care, I don't care if they call us crazy & Repetition, consonance \\
\hline 17. & Runaway to a world that we design & Imagery, symbol, consonance \\
\hline 18. & However big, however small, let me be part of it all & Symbol, repetition \\
\hline 19. & Share your dreams with me & Symbol, idioms \\
\hline 20. & $\begin{array}{l}\text { You may be right, you may be wrong but say that } \\
\text { you'll bring me along to the world you see }\end{array}$ & Repetition, imagery, symbol \\
\hline 21. & To the world I close my eyes to see & Imagery, symbol, hyperbole, paradox \\
\hline
\end{tabular}

Figurative

learning,

Moral

interpretation

From Diagram 1 above, it can be seen that there are 13 imageries (20,6\%), 4 personifications (6,3\%), 2 paradoxes (3,7\%), 14 symbols (22,22\%), 6 idioms $(9,52 \%), 9$ hyperboles $(14,28 \%), 8$ repetitions $(12,69 \%), 1$ simile (1,58\%), 1 metaphor (1,58\%), 1 assonance $(1,58 \%)$, and 6 consonances $(9,52 \%)$. If it is seen from Table 1 , it can be learned that all lines in the lyric are composed using more than one figurative language. There are several lyrics in the song that consist of four figurative languages, such as in "I close my eyes and I can see the world that's waiting up for me that I call my own" which use imagery, personification, symbol, and paradox; and "we can live in a world that we design" which use imagery, idiom, symbol, and consonance. Nevertheless, there are also some lyrics using only two figurative expressions as in "there's a house we can build" (symbol and imagery), "however big, however small let me be part of it all" (symbol and repetition), and "share your dreams with me" (symbol and idiom).

In details, the frequently used figurative language is symbol. It indicates that the songwriters would like to express their feelings in realistic ways through symbols, so the 
Figurative learning, Moral interpretation

readers/listeners might depict or interpret them pragmatically. For example, in the lyric "I close my eyes and I can see the world that's waiting up for me that I call my own", the word "world" does not mean the Earth with its continents, countries, or other demographic stuffs; but it refers to a different meaning which can be interpreted to symbolize the songwriters' future life that they have been waiting excitedly. In another viewpoint, the word 'world' is used to depict a colorful, larger, challenging, excited, and distinctive life ahead. Another example can also be seen in the word "dreams" in the lyric "a million dreams are keeping me awake". The word "dreams" does not refer to the common dreams that come when sleeping; but it is more to the vision or fantasy of the songwriters towards their future lives.

The second most used figurative expression is imagery. Imagery refers to a figurative expression that allows people to depict the situation and ambience of the utterances. In A Million Dreams song, imagery is used to let the readers/listeners to portray the deliberate contexts proposed by the songwriters. For example, in the lyric "cause every night I lie in bed, the brightest colors fill my head", the songwriters use a phrase "the brightest colors" to touch the senses of the readers/listeners (especially sight) to imagine their excitements towards ideas or visions in their minds. Another example is in the lyric "you may be right, you may be wrong but say that you'll bring me along to the world you see". In this lyric, the keyword of imagery is "to the world you see", again, the songwriters through the phrase that represents sight sense deliberately lead the readers/listeners to imagine and interpret how the world that they have designed.

Besides those two dominant figurative languages, the songwriters also used personification, idiom, and hyperbole at the same time in the lyric "a million dreams are keeping me awake". In this lyric, personification is used to the word "dreams". The songwriters personified or gave human attribute to the dreams as if they can make a person awake. Literally, in reality, inanimate objects such as dreams cannot make people awake because they are not alive. However, in order to give quality of the objects the songwriters attributed human traits on them (Rankin, 2020). For the idiom, in that lyric, the phrase "keeping me awake" has an idiomatic meaning that the writers feel excited and enthusiastic towards their ideas, plans, or visions. Lastly, for the hyperbole, the songwriters used the word "million" attached to the dreams with the purpose of emphasizing on numerous visions or plans they have for their future. This exaggeration is aimed to give amusing 
effect to the thoughts or feelings so that the people who listen or read would feel the thrills (Claridge, 2011).

If it is seen from the various types of the figurative languages that the songwriters

used, it can be comprehended that the song does not refer to any literal meaning of the utterances. Instead, it is written in metaphorical or non - literal expressions. From the title, for example, the phrase A Million Dreams essentially does not talk about the numbers of the literal dreams, but it is a hyperbolic expression of countless visions and expectations that the songwriters have for their future lives. From a semantic perspective, language is a very generic representation that ones can have various interpretations or even symbol grounding problems if they do not embrace the pragmatic parsing during interpreting (Klapuri, 2007). As in this song, it could include the storyline of the movie that talks about struggles of Phineas Taylor Barnum in making his circus internationally debuted, and the singer of the song, a young man with big dreams to succeed and live better. Therefore, in order to succeed construing the meanings this A Million Dreams song, it is crucial for us as the readers/listeners to also include the rational situation in our interpretations. If not, failing to grab the deliberate meaning of the song cannot be helped.

\section{Moral interpretations}

Literary works are created with deliberate intentions. They are not written or produced only to entertain the readers/listeners, but also to provide lessons, as well. In $A$ Million Dream song, there are at least two moral lessons that the readers/listeners of the song can grab. The first is related to pursuing dreams. This lesson can be pragmatically interpreted from the singer who was a young boy. It expects the readers/listeners especially young people to understand that dreaming about future is something that they have to do which might lead to sustainable development (Bardales \& Arenas, 2014). From a very young age, people need to have goals and targets to achieve. They have to live with settled plans. Their dreams have to be the big ones. Even, if it is something irrational for others, as long as the plans have settled ways, it can be possible. This song also teaches people that they have to struggle with their lives because there would be challenges and obstacles that they have to encounter in front.

The second moral that can be learned is related to live hand in hand with others. In the lyric, the songwriters used pronoun we which refers to more than one person. The 
Figurative learning, Moral interpretation

\section{2}

lyric "we can live in a world that we design" and "however big, however small, let me be part of it all. Share your dreams with me", teach people that having companions is a necessity. Naturally, people need to live side by side. When people have companions, who share the same visions, targets and goals are more possible to reach. Moreover, their confidence towards abilities and passions will improve significantly as they have friends to talk to, to share with, and to motivate them.

\section{CONCLUSION}

Literary works do contain entertainment function. In spite of it, they also contain educative elements which are beneficial for the English language learners, such as figurative language and moral values. As in A Million Dreams song, English learners can learn and understand eleven types of figurative languages such as imagery, personifications, paradoxes, symbols, idioms, hyperboles, repetitions, simile, metaphor, assonance, and consonances, as well as two moral values that are beneficial for them. By knowing these literary devices and literary elements, they could get more than just textbooks knowledge. They can lean more sophisticated vocabulary and expressions; even learn to create relationship between utterances and contexts to understand or build meanings from the expressions.

\section{REFERENCES}

Aprianti, A., Zulfadhli, \& Thahar, H. E. (2012). kategori dan fungsi majas dalam lirik lagu album bintang 5 dewa 19. Jurnal Pendidikan Bahasa dan Sastra Indonesia, 1-8.

Arifah, K. (2016). figurative language analysis in five John Legend's song. Malang: Maulana Malik Ibrahim State Islamic University of Malang.

Bardales, D., \& Arenas, P. (2014). The world we want: a young person's guide to the global goals and sustainable development. Carribean: Global Movement of MMILAC.

Baumbach, S., Grabes, H., \& Nünning, A. (2009). Values in literature and the value of literature: literature as a medium for representing, disseminating and constructing norms and values. Trier: Wissenschaftlicher Verlag Trier.

Cardin, S. A. (2009, September 30). Sharing of figurative language themes in expert therapy: occurrence and effect on client experiencing and therapeutic bond. Retrieved from Texas A\&M University Libraries: http://oaktrust.library.tamu.edu/handle/1969.1/532 
Claridge, C. (2011). Hyperbole in English: a corpus-based study of exaggeration. Cambridge: Cambridge University Press.

Doiz, A., \& Elizari, C. (2013). metaphoric competence and the acquisition of figurative vocabulary in foreign language learning. Estudios de Linguistica Inglesa Aplicada, 47-82.

Egilmez, H. O. (2016). Effects of songs containing social messages on the perceptions of Romani students about social values. Anthropologist, 591-597.

Harya, T. D. (2016). an analysis of figurative languages used in Coelhos's novel entitled "alchemist". Premise Journal, 45-63.

Hendrawaty, N., \& Nurhayati. (2019). the influence of listening English pop songs to improve learners' vocabulary at LKP Nuansa Jaya. Loquen: English Studies Journal, 56-65.

Henkemans, F. S. (2013). the use of hyperbole in the argumentation stage. the 10th International Conference of the Ontario Society for the Study of Argumentation (pp. 1-9). Ontario: University of Windsor.

Islami, M. B. (2019). Figurative language used in Deep Purple song lyrics:stylistic analysis. Yogyakarta: Universitas Ahmad Dahlan.

Keraf, G. (2009). diksi dan gaya bahasa. Jakarta: Gramedia.

Klapuri, A. (2007). Semantic analysis of text and speech. Finland: Tampere University of Technology.

Kuśnierek, A. (2016). the role of music and songs in teaching English. World Scientific News, 1-55.

Listiani, H. (2015). An analysis of figurative language found on the song lyric by Taylor Swift's "speak now" album. Salatiga: State Institue for Islamic Studies.

MacArthur, F. (2010). Metaphorical competence in EFL: Where are we and where should we be going? A view from the language classroom. AILA Review, 73-155.

Melion, W. S., \& Remakers, B. (2016). personification : an introduction. Leiden: Brill.

Millington, N. T. (2011). using songs effectively to teach English to young learners. Language Education in Asia, 134-141.

Ningsih, N. (2019). The Effect of Song in Teaching English. ELTIES Journal, 1-12.

Oroujlou, N. (2012). The importance of media in foreign language learning. ProcediaSocial and Behavioral Sciences, 14-18.

Padillah, E. N., Firmawan, H., \& Purwaningsih, E. (2016). simile, hyperbole, personification, and metaphor used in Gayle Forman's if i stay. Journal of Language and Literature, 69-78.

Pratiwi, E. (2018). Using songs to enhance learning in English the classroom. Seminar Nasional Pendidikan Universitas PGRI Palembang (pp. 369-274). Palembang: Universitas PGRI Palembang.

Rankin, A. (2020, July 19). What is the function of personification in song? Retrieved from Wisegeek: https://www.wisegeek.com/what-is-the-function-ofpersonification-in-songs.htm

Rohani, T., Arsyad, S., \& Diani, I. (2018). semantic analysis of figurative language expressionsin "feature" of the Jakarta Post. Journal of Applied Linguistics and Literature, 1-18.

Sari, N. (2013). The Importance of Teaching Moral Values to the Students. Journal of English and Education, 154-162. 
Figurative learning, Moral

interpretation Shen, C. (2009). using English Songs: an enjoyable and effective approach to ELT . English Language Teaching, 88-94.

Setiawan, A. A. (2014). Figurative language analysis in song lyrics of Coldplay band. Jurnal Ilmiah Mahasiswa FIB.

124 